\title{
CONFRONTING SOCIAL MEDIA IN HIGHER EDUCATION
}

\author{
Jolita Šliogerienè \\ Mykolas Romeris University \\ Faculty of Politics and Management \\ Institute of Philosophy and Humanities \\ Ateities str. 20, \\ LT-08303 Vilnius, Lithuania \\ E-mail: j.sliogeriene@gmail.com \\ Tel.: (+370) 68652240

\section{Giedrè Valūnaite Oleškevičienè} \\ Mykolas Romeris University \\ Faculty of Politics and Management \\ Institute of Philosophy and Humanities \\ Ateities str. 20, \\ LT-08303 Vilnius, Lithuania \\ E-mail: gentrygiedre@gmail.com \\ Tel.: (+370) 68694276
}

Received on 5 August, 2014; accepted 25 September, 2014

doi:10.13165/SMS-14-6-2-10

\begin{abstract}
Social media is becoming more and more pervasive in all aspects of life, including education. As social media application is a comparatively new research field, the discourse on its application in education environments is often contradictory. Thus, literature review is carried out to identify the main trends and issues in the emerging research and theories on social media use in higher education. First, the background


of higher education modernization and technological influence is reviewed, paying attention to the effects of social media application in the sphere of higher education. Various forms of social media and transitional media applications, such as course management systems, are discussed concerning their use in educational environments. Also, a note is taken of new emerging educational theories concerning learning based on technological change and social media use. It is noted that the initial enthusiasm about social media application in higher education is changed by sober understanding of social media integration into higher education contexts.

Keywords: social media, higher education, Web 2.0, student-centeredness, social media literacy, learning.

\section{Introduction}

Web 2.0 technologies and social media are comparatively new applications in educational environment, so the discourse about social media use in higher education is often contradictory, starting with absolutely enthusiastic approaches predicting total advancement fueled by social media and facing totally critical views towards social media as disruptive technologies hardly suitable for educational purposes. However, the vigorous development of social media and other Web 2.0 technologies seems to be pervasive to all spheres of life (Lenhart, Purcell, Smith \& Zickuhr, 2010) ${ }^{1}$, and social media seems here to stay and cause inevitable changes or applications in higher education.

Today's higher education provision is characteristic of variety, ranging from "brick and mortar" forms to hybrid and totally virtual classes. Social media being widely used for business and personal purposes is also a powerful tool used in the educational environment. So, it is worthwhile researching the variety of discourses concerning social media use in higher education with the purpose to find out the main prevailing trends in the use of social media in higher education.

The review begins with the literature review as a methodology. It is succeeded by the background information on higher education modernization which is getting tightly connected with technology application in education where technology acts as a driving force as well as inner processes in higher education cause to apply the newest technologies to satisfy the demands of emerging needs and changes in the dynamic of higher education. Course management systems as a transitional link and various forms of social media are discussed, including media choices according to learning objectives. Discussions on pedagogical change and new emerging theories concerning learning are overviewed.

1 Lenhart, A., Purcell, K., Smith, A., \& Zickuhr, K. (2010). Social Media and Mobile Internet Use Among Teens and Young Adults, p. 1-51. 


\section{Methodology}

A review of literature was carried out systematically searching databases, such as EBSCO host and ERIC. Also, Google Scholar was used for searching scholarly articles dealing with social media and higher education matters. The "snowball" method was used finding the articles and getting deeper into the cited in the previous ones. It is likely that some literature sources could be missed in the vast ocean of the emerging scientific literature on social media research; however, the overview was focused on the main trends and emerging theories in the analysed sphere.

\section{Social Media Application in Higher Education}

Higher education is heavily influenced by various societal and technological factors and appearance, and application of social media induces certain shifts and reflections on the ongoing processes. Bach, Haynes and Smith $(2007)^{2}$ foresee an extensive growth of technology use and online learning in higher education due to the following factors:

- Rapid technological change which naturally pervades all spheres of life, including education;

- Availability of online technologies due to the fact that provision with technology is becoming more and more accessible. Changing students lifestyles to acquire a part-time job alongside their studies due to the economic and social conditions;

- Increase in student IT skills as the new generation acquire the skills naturally;

- Growth of higher education to satisfy a growing demand for mass higher education;

- Growth of higher education in the global market fueled by the demand for higher education;

- Globalization processes and the need for international study experience, cooperation and global networks.

\subsection{Course Management Systems as a Transitional Link}

Currently, many universities and other institutions of higher education use CMS (Course Management Systems), such as Blackboard, Sakai and Moodle. They are used to present course materials, to ensure interaction between lecturers and their students and between peers. CMS are stated to be compatible with student-centered approaches based on constructivist theories. Students are enabled to discover and

2 Bach, S., Haynes, P., \& Smith, J. L. (2007). Online Learning and Teaching in Higher Education. London: Mc Graw-Hill, p. 27. 
work out the concepts and knowledge using critical analysis and reflection. Multiple information resources on the web, peer discussions, tutor guidance and collaborative activities combined together allow individual students to construct their knowledge of a subject. For example, Dougiamas $(2002)^{3}$, the creator of Moodle, suggests five social constructionist features reflected in Moodle:

1. In a really collaborative environment the participants of educational processes become both teachers and learners.

2. Learning is stimulated by creating or expressing something for others.

3. Learning takes place by just observing the activity of our peers.

4. Understanding the context of others enables teaching in a more transformational way.

5. Flexibility and adaptability of the learning environment give possibilities to respond to the needs of the course participants.

However, some authors express reservations as CMS are just tools designed along the theories of social constructivism and just using the tools does not ensure the application of constructivist principles, the instructor need to apply the methods and approaches which go in line with constructivist theories. McLoughlin and Lee $(2008)^{4}$ express their views that CMS just replicate traditional paradigms in online environments, where traditionally students are approached as information consumers. Other authors Bryer and Chen $(2012)^{5}$ note that CMS give limited opportunities for online sharing and collaboration as student interaction activities are restricted to one class or one semester, while in comparison social media tools give a constant opportunity of sharing many-to-many. Although CMS have social media features, there are as well institutional security and privacy requirements which do not allow sharing beyond the limits of an institution.

\subsection{Social Media Use for Learning}

Social media has many various forms, including internet forums, blogs, wikis, social networks, podcasts, photos, video, social bookmarking. If teacher beliefs are based on social constructivist approach viewing learning as based on social collaboration, the use of wiki media could be a choice for implementing group projects. In onsite environments students are organized in groups to work together on project tasks, while wiki media allows students to collaborate online fully without meeting face-to-face.

3 Dougiamas, M., \& Taylor, P. C. (2002). Interpretive Analysis of an Internet-based Course Constructed Using a New Courseware Tool Called Moodle. 2nd Conference of HERDSA (the Higher Education Research and Development Society of Australasia), p. 7-10.

4 McLoughlin, C., \& Lee, M. J. W. (2008). Future Learning Landscapes: Transforming Pedagogy through Social Software. Innovate: Journal of Online Education, 4(5): 28-43.

5 Bryer, T. A., \& Chen, B. (2012). Investigating Instructional Strategies for Using Social Media in Formal and Informal Learning. The International Review of Research in Open and Distance Learning, 13(1). 
Blogs are different from wikis as they do not have the characteristic of multiauthorship, blogs are usually created and run by one author inviting the comments from the blog followers. So, if the learning objective is to encourage students to express their ideas, publicize them, to foster their feeling of being confident and outspoken, then blogs seem to be an appropriate media choice. If the learning focus is to develop students' verbal articulation, the podcasts may seem a reasonable choice. What is more, if an open discussion needs to be encouraged and students' negotiating skills, expressing opinions and exchanging ideas, is the learning objective, then computer conferencing or internet forum seems to be an option.

\subsection{Pedagogical Change}

"If you took a doctor from the 19th century and put her in a modern operating theatre, she would have no idea what to do, but if you put a teacher from the 19th century into a modern classroom, she would be able to carry on teaching without a pause. The idea remains that students are empty containers which the teacher fills with the knowledge" (by anonymous).

When reflecting on the quote from an English textbook, which the author of this article used for teaching in 2006, the author thinks that in a modern classroom equipped with all the technology a teacher from the 19th century would get puzzled, but, what concerns pedagogy, the idea of the necessity to fill students with knowledge, criticize unexpected approach, desire to instruct, control, test and measure still prevail in many educational contexts. However, it is felt that constructivist approach or student-centered learning is more compatible with web 2.0 tools and technologies. Open-ended approach based on constructivist theory provides students with opportunities to contextualize learning and negotiate knowledge in a collaborative way which is in line with the basic ideas of constructivism:

- Learning is an active process of constructing knowledge rather than acquiring it.

- Instruction is a process that involves supporting that construction rather than communicating knowledge (Duffy and Cunningham, 1996) ${ }^{6}$.

Learner-centered model is favored which supports and guides the learner in the construction process of learner understanding of the reality of which he is a part (Duffy and Cunningham, 19967 ; Laurillard, 1999 ${ }^{8}, 2002^{9}$ ). As well, researchers point

6 Duffy, T. M., \& Cunningham, D. J. (1996). Constructivism: Implications for the Design and Delivery of Instruction. In D. H. Jonassen (ed.). Handbook of Research for Educational Communications and Technology. NY: Macmillan Library Reference.

$7 \quad$ Ibid., p. 113.

8 Laurillard, D. (1999). Using Communications and Information Technology Effectively. In W. J. McKeachie and G. Gibbs. McKeachie's Teaching Tips: Strategies, Research and Theory for College and University Teachers. Boston: Houghton Miffin Co.

9 Laurillard, D. (2002). Rethinking University Teaching: A Conversational Framework for the Effective Use of Learning Technologies. London: Routledge Falmer. 
out the importance of learning based on authentic tasks embedded in the context as learning is viewed as based on socio cultural dialogue (Lave and Wenger, 1991) ${ }^{10}$. In fact, there could be observed an inter-related process that technological development provides ICT rich learning environments, including social software tools, at the same time fueling the change of learning paradigms, which is identified by researches as a need for pedagogical change.

"[...] and requires the development of learning episodes for pupils that have dialogue and communication as core features. From this perspective, there is a far greater emphasis on networked rather than linear models of learning and on providing culturally relevant experiential and purposeful learning episodes that than the consumption of abstract knowledge [...]" (Rudd, Sutch and Facer, 2006) ${ }^{11}$.

Thus, pedagogy is naturally influenced by social media development, and new concepts and approaches seem to thrive in the environment permeated with social media.

\subsection{New Emerging Theories}

The emergence of new theories marks new demands for learning and working in social media environment characterized by highly social collaborative nature and constant immersion in the ocean of information.

In conversation theory, Laurillard $(2002)^{12}$ stresses the importance of on-going teacher-learner interaction, in such a way giving importance to interactivity. Siemens $(2004)^{13}$ describes connectivism as "the integration of principles explored by chaos, network, and complexity and self-organization theories" and presents learning as a process which "[...] is focused on connecting specialized information sets, and the connections that enable us to learn more are more important than our current state of knowing". Siemens (2004) $)^{14}$ identifies essential learning skills and principles, stressing that many learners move into a variety of different, possibly unrelated fields over the course of their lifetime and technology is altering (rewiring) our brains and the tools we use to define and shape our thinking.

10 Lave, J., \& Wenger, E. (1991). Situated Learning: Legitimate Peripheral Participation. Cambridge: Cambridge University Press.

11 Rudd, T., Sutch, D., \& Facer, K. (2006). Towards New Learning Networks. Bristol, England: Futurelab.

12 Laurillard, D., supra note 9, p. 128.

13 Siemens, G. (2004). Connectivism: A Learning Theory for the Digital Age. International Journal of Instructional Technology and Distance Learning, 2(1): 3-11. 
Table 1. Recent Educational Theories

\begin{tabular}{|l|l|l|}
\hline \multicolumn{1}{|c|}{ Theory \& author } & \multicolumn{1}{|c|}{ Main insights } & \multicolumn{1}{c|}{ Pedagogical ideas } \\
\hline $\begin{array}{l}\text { Conversation theory } \\
\text { Laurillard, 2002) }\end{array}$ & $\begin{array}{l}\text { The conversational approach looks } \\
\text { at the on-going learner-teacher } \\
\text { interaction, at the process of } \\
\text { negotiation of views of the subject- } \\
\text { matter which takes place between } \\
\text { them in such a way as to modify } \\
\text { the learner's perceptions. }\end{array}$ & $\begin{array}{l}\text { Students to learn relationships } \\
\text { among the concepts and ideas } \\
\text { trough explicit conversations with } \\
\text { teachers regarding subject matter. } \\
\text { Student understanding is facili- } \\
\text { tated through reciprocal dialogue. }\end{array}$ \\
\hline $\begin{array}{l}\text { Connectivism } \\
\text { (Siemens, 2004) }\end{array}$ & $\begin{array}{l}\text { A theory that integrates principles } \\
\text { explored by chaos, complexity } \\
\text { theory and networking, mainly } \\
\text { stating that making and sustaining } \\
\text { connections is more important } \\
\text { than simply knowing. }\end{array}$ & $\begin{array}{l}\text { Learning process is characterized } \\
\text { by connecting various types of } \\
\text { information and by enabling } \\
\text { learners to see the connections } \\
\text { between concepts and ideas. } \\
\text { cearners need competencies } \\
\text { what to learn and the meaning of } \\
\text { incoming information. }\end{array}$ \\
\hline $\begin{array}{l}\text { Navigationism } \\
\text { (Brown, 2005) }\end{array}$ & $\begin{array}{l}\text { Navigationism is a more inclusive } \\
\text { term than constructivism, it } \\
\text { includes knowledge creation and } \\
\text { ability to manipulate, evaluate } \\
\text { and navigate knowledge as well as } \\
\text { being able to share knowledge in } \\
\text { the process of knowledge creation. }\end{array}$ & $\begin{array}{l}\text { Learning is about learner } \\
\text { interaction with information and } \\
\text { people and about the skills and } \\
\text { competencies learners require in } \\
\text { order to survive in the knowledge } \\
\text { era. }\end{array}$ \\
\hline
\end{tabular}

Source: McLoughlin \& Lee $(2008)^{15}$

In navigationism, Brown $(2005)^{16}$ focuses on student ability to navigate the surplus of knowledge. He states that it is important for students to be able to collaboratively explore, evaluate, manipulate and integrate knowledge available in various sources and modes. Brown identifies certain skills and competencies required in a navigationist paradigm. As well, Brown $(2005)^{17}$ provides a summary of the connectivist learning skills and principles required within a navigationist learning paradigm.

The author identifies that certain learning principles intertwine in both theories. The emergence of new theories and the need for them is related to the nature of social media which turns learning from an act of an individual nature into an act of

15 McLoughlin, C., \& Lee, M. J. W., supra note 4, p. 28-43.

16 Brown, T. (2006). Beyond Constructivism. Navigationism in the Knowledge Era. On the Horizon, 14(3): 108-120.

17 Ibid., p. 108-120. 
collective nature embedded into the new realities of social media. Oakeshott $(1989)^{18}$, advocating for his holistic approach to the essence and function of university education, which is "teaching to see" not just simply learning certain skills, stresses the importance of broader understanding of higher education and education itself. Here it seems that holistic approach to learning and living in any reality has been embedded already in holistic approaches by Lao: "Earthly truths are limited and contradict each other. They lead to common truths but common truths do not obey order and lead to what cannot be ordered" (Lao, 2009) ${ }^{19}$.

It becomes so visible now with the fast developing technologies creating new emerging realities and the need for a learner to be ready to constantly navigate and learn in the fluid world of ever changing information and technology. What existed yesterday has been changed by today's reality and what exists today is going to be changed by tomorrow's reality and people need to learn to live in the constant change.

\subsection{Flexible Learning}

It appears that student-centeredness, flexibility, interactivity and dynamic learning environment are the central features for having rationale for the choice of media and methods. Mason and Rennie (2008) ${ }^{20}$ identify that flexible learning is not a new phenomenon. In fact, learning takes place both in the environments of formal education and out of formal settings. Collins and Moonen (2001) ${ }^{21}$ defined four key features of flexible learning:

- Technology;

- Pedagogy;

- Implementation strategies;

- Institutional framework.

But most importantly, they stressed the necessity that flexible learning should be focused on the benefits of the learner: "Flexible learning is a movement away from a situation in which key decisions about learning dimensions are made in advance by the instructor or institution, towards a situation where the learner has a range of options from which to choose with respect to these key dimensions" (Collins and Moonen, 2001 ${ }^{22}$.

18 Oakeshott, M. (1989). The Idea of University. In T. Fuller (ed.). The Voice of Liberal Learning/ Michael Oakeshott on Education. New Haven and London: Yale University Press, p. 98.

19 Lao, T. (2009). Lao-Tzu's Tao Teaching. 3rd revised edition. Porter, Bill (Red Pine), Port Townsend, WA: Copper Canyon Press.

20 Mason, R., \& Rennie, F. (2008). E-learning and Social Networking Handbook. London, UK: Routledge, p. 35.

21 Collis, B., \& Moonen, J. (2001). Flexible Learning in a Digital World. Experiences and Expectations. UK: Kogan Page Limited. Ibid., p. 54. 
However, it is not as easy as it may seem at first sight. Social media just used by itself will not make the existing face-to-face course more interactive, nor will it solve the problems of the existing course. If the on-site course material, handouts and reading resources are directly uploaded on social media sites without any modifications, the problems, such as lack of student participation, remain the same, so as to rephrase the thought, all the advantages and disadvantages of the existing onsite courses are pasted onto social media websites. In such a way social media does not work as a panacea. Actually, pedagogy, the understanding of educational aim, remains of the key importance (Biesta, 2013) ${ }^{23}$. The choice of media and activities within it depend on the educational goal. Social media could be used in the variety of ways and what works in one situation not necessarily works in another one. The responsibility of a teacher is to orchestrate the technological means and course materials in tune with the educational goal.

Additionally, it is important to make sure the students are comfortable with the technology while using social media. Students should focus attention on the activity instead of wasting their time on figuring out social media applications or being distracted by feeling uncomfortable with the technology.

It is also important that activities are worthwhile doing, related to real life experience and have clear learning benefits as students are concerned about using their time effectively. In attention economics approach, human attention is treated as a scarce commodity. According to Davenport and Beck $(2001)^{24}$, attention is focused as a mental engagement on a particular item of information. Items come into our awareness, we attend to a particular item, and then we decide whether to act. Within the growing abundance of information in social media, human attention becomes a limiting factor in such a way that clear and transparent learning benefits might become a factor for retaining students' attention in the opposite situation; thus, students may focus their attention and spend time elsewhere.

\section{Conclusion}

To conclude, it would be rational to quote what Selvyn $(2012)^{25}$ observes that the ongoing debate is still not based on substantial research and is of a more speculative nature. In fact, social media use in higher education is not totally positive or totally negative and should be analyzed in more disputable terms, including advantages and disadvantages. The author also observes that the wider context of social media use in higher education remains contradictory, as well. On the one hand, Web 2.0

23 Biesta, G. J. J. (2013). The Beautiful Risk of Education. London: Paradigm Publishers, p. 136.

24 Davenport, T. H., \& Beck, J. C. (2001). The Attention Economy: Understanding the New Currency of Business. Harvard Business School Press.

25 Selwyn, N. (2012). Social Media in Higher Education. The Europa World of Learning 2012. Routledge. 
technology and its applications, such as social media, are promising technologies designed with inhered ability to enhance teaching/learning processes by providing opportunities to create and share content at unprecedented speed and quantities. However, there remains a concern that optimistic expectations about social media enhanced collective creativity seem to be far-fetched. The majority of users of social media applications prefer passive use of knowledge. User creative activities are mostly limited by profile creation, such a situation could be characterized by the economic term "logic of collective action", when majority uses the content created by minority (Selvyn, 2012) ${ }^{26}$. Actually, the situation could be described in Gouseti's words $(2010)^{27}$, "a cycle of hype, hope and disappointment", reflecting the situation when at the initial state there is sometimes exaggerated enthusiasm which later develops into logical understanding. In this more realistic context, broader research should be carried out on integration of social media into institutionalized educational environments of higher education.

\section{References}

Bach, S., Haynes, P., \& Smith, J. L. (2007). Online Learning and Teaching in Higher Education. London: McGrawHill.

Biesta, G. J. J. (2013). The Beautiful Risk of Education. London: Paradigm Publishers.

Brown, T. (2006). Beyond Constructivism. Navigationism in the Knowledge Era. On the Horizon, 14(3): 108-120.

Bryer, T. A., \& Chen, B. (2012). Investigating Instructional Strategies for Using Social Media in Formal and Informal Learning. The International Review of Research in Open and Distance Learning, 13(1).

Collis, B., \& Moonen, J. (2001). Flexible Learning in a Digital World. Experiences and Expectations. UK: Kogan Page Limited.

Davenport, T. H., \& Beck, J. C. (2001). The Attention Economy: Understanding the
New Currency of Business. Harvard Business School Press.

Dougiamas, M., \& Taylor, P. C. (2002). Interpretive Analysis of an Internetbased Course Constructed Using a New Courseware Tool Called Moodle. 2nd Conference of HERDSA (the Higher Education Research and Development Society of Australasia), p. 7-10 [interactive]. [accessed on June, 2014]. <http://online.dimitra.gr/sektrainers/ file.php/1/MartinDougiamas $>$.

Duffy, P. D., \& Bruns, A. (2006). The Use of Blogs, Wikis and RSS in Education: A Conversation of Possibilities. Proceedings of the Online Learning and Teaching Conference 2006, Brisbane, Australia, p. 31-38.

Duffy, T. M., \& Cunningham, D. J. (1996). Constructivism: Implications for the Design and Delivery of

26 Ibid., p. 79.

27 Gouseti, A. (2010). Web 2.0 and Education: Not Just Another Case of Hype, Hope and Disappointment? Learning, Media and Technology, 35(3): 351-356. 
Instruction. In D. H. Jonassen (ed.). Handbook of Research for Educational Communications and Technology. NY: Macmillan Library Reference.

Focus on Higher Education in Europe 2010: The Impact of the Bologna Process [interactive]. [accessed on June, 2014]. <http://eacea.ec.europa. eu/education/eurydice./documents/ thematic_reports/122EN.pdf $>$.

Gouseti, A. (2010). Web 2.0 and Education: Not Just Another Case of Hype, Hope and Disappointment? Learning, Media and Technology, 35(3): 351-356.

Lao, T. (2009). Lao-Tzu's Tao Teaching. 3rd revised edition. Porter, Bill (Red Pine), Port Townsend, WA: Copper Canyon Press.

Laurillard, D. (1999). Using Communications and Information Technology Effectively. In W. J. McKeachie \& G Gibbs. McKeachie's Teaching Tips: Strategies, Research and Theory for College and University Teachers. Boston: Houghton Miffin Co.

Laurillard, D. (2002). Rethinking University Teaching: A Conversational Framework for the Effective Use of Learning Technologies. London: Routledge Falmer.

Lave, J., \& Wenger, E. (1991). Situated Learning: Legitimate Peripheral Participation. Cambridge: Cambridge University Press.

Lenhart, A., Purcell, K., Smith, A., \& Zickuhr, K. (2010). Social Media and Mobile Internet Use Among Teens and Young Adults [interactive]. [accessed June, 2014]. <http://www.pewinternet. org $>$.
Mason, R., \& Rennie, F. (2008). E-learning and Social Networking Handbook. London, UK: Routledge.

McLoughlin, C., \& Lee, M. J. W. (2008). Future Learning Landscapes: Transforming Pedagogy through Social Software. Innovate: Journal of Online Education, 4(5) [interactive]. [accessed on June, 2014]. <http://innovateonline. info/?view $=$ article\&id $=539>$.

Oakeshott, M. (1989). The Idea of University. In: T. Fuller (ed.). The Voice of Liberal Learning/Michael Oakeshott on Education. New Haven and London: Yale University Press.

Rudd, T., Sutch, D., \& Facer, K. (2006). Towards New Learning Networks. Bristol, England: Futurelab [interactive]. [accessed on June, 2014]. <http://www. futurelab.org.uk/resources/documents/ opening_education/Learning_ Networks_report.pdf $>$.

Selwyn, N. (2009). Faceworking: Exploring Students' Education-related Use of Facebook. Learning, Media and Technology, 34(2): 157-174.

Selwyn, N. (2012). Social Media in Higher Education. The Europa World of Learning 2012, Routledge [interactive]. [accessed on June, 2014]. <http://www. educationarena.com/pdf/sample/ sample-essay-selwyn.pdf $>$.

Siemens, G. (2004). Connectivism: A Learning Theory for the Digital Age. International Journal of Instructional Technology and Distance Learning, 2(1). 


\title{
ŽVELGIANT I SOCIALINES MEDIJAS AUKŠTAJAME MOKSLE
}

\author{
Jolita Šliogerienė, Giedrè Valūnaite Oleškevičienė \\ Mykolo Romerio universitetas, Lietuva
}

Santrauka. Saityno 2.0 technologijos ir ju pritaikymas, toks kaip socialines medijos, yra palyginti naujas švietimo aplinkoje, todèl diskursai, analizuojantys socialines medijas ir jų taikyma švietime ir konkrečiai aukštajame moksle, dažnai yra prieštaringi, apimantys nuo visiškai entuziastingu požiūrių, kurie numato galinga pažanga, inspiruota socialiniu mediju vystymosi ir taikymo aukštajame moksle, iki visiškai kritišku požiüriu, išreiškiančiu abejones dèl socialiniu mediju taikymo aukštajame moksle, pristatančiu socialines medijas kaip visiškai ardančias ar trikdančias švietimo procesu darna ir netinkamas taikyti aukštajame moksle.

Tačiau sparčiai besivystančios socialinès medijos ir kitos saityno 2.0 technologijos, moksliniu tyrimu duomenimis, vis labiau skverbiasi i visas gyvenimo sritis (Lenhart, Purcell, Smith, \& Zickuhr, 2010), ju naudojimas ivairiais tikslais vis labiau isitvirtina atnešdamas neišvengiamus pokyčius visose srityse, taip pat ir aukštajame moksle. Šiuolaikinis aukštasis mokslas pasižymi tuo, kad egzistuoja aukštojo mokslo prieinamumo formu ivairove, pradedant nuo realiu fiziniu instituciju, vadinamuju „plytu ir cemento" formų, kur užsièmimai vyksta realiu laiku, realioje fizinejje institucijoje, pereinant prie hibridiniu formu, mišraus mokymo(si) paslaugu, kur dalis mokymo(si) vyksta virtualioje erdveje, ir galiausiai visiškai virtualiu klasiu ir virtualių mokymo(si) formų.

Taigi yra svarbu apžvelgti egzistuojančiq diskursü, susijusiu su socialiniu mediju taikymu aukštajame moksle, ịvairovę, bandant išsiaiškinti pagrindines egzistuojančias socialiniu mediju taikymo aukštajame moksle kryptis, problematika ir perspektyvas.

Apžvalgine literatūros analizè prasideda literatūros analizès metodologijos pristatymu. Remiantis mokslinès literatūros ǰžvalgomis aptariama pagrindine informacija aukštojo mokslo modernizavimo klausimais, inspiruotais socialiniu mediju vystymosi ir galingo skverbimosi ị aukštojo mokslo erdvę. Socialines medijos ir technologijos veikia kaip varomoji jèga, skatinanti aukštojo mokslo procesu kaita. Tuo pat metu egzistuoja ir vidinés jègos, skatinančios aukštojo mokslo procesų kaita ir aktyvu socialiniu mediju taikymą. Tai pirmiausia augantis aukštojo mokslo populiarumas ir poreikis, kuri padeda patenkinti socialiniu mediju taikymas modernizuojant aukštojo mokslo procesu valdyma ir prieinamuma plačiajai visuomenei. Aptariamos žiniatinklinès virtualaus mokymosi aplinkos kaip pereinamoji grandis i i ivairiu socialiniu mediju formu taikyma aukštajame moksle. Pristatomos įvairios socialiniu mediju formos ir ju galimas taikymo pasirinkimas atsižvelgiant i mokymosi tikslus. Taip pat analizuojamas pedagoginis pokytis, vadinamosios saityno 2.0 pedagogikos atsiradimas, pristatomos įvairios naujos mokymosi teorijos. Galiausiai apibendrinama, remiantis ižvalgomis (Selvyn, 2012), kad požiüris i socialinių mediju taikyma aukštajame moksle kito nuo perdètai entuziastingo iki blaiviai ịvertinančio socialiniu mediju taikymo aukštajame moksle teikiamas galimybes ir perspektyvas. 
Reikšminiai žodžiai: socialinès medijos, aukštasis mokslas, saitynas 2.0, ị studentą orientuotas požiūris, mokymasis.

Jolita Šliogerienė, Mykolo Romerio universiteto Politikos ir vadybos fakulteto Filosofijos ir humanistikos instituto profesorè. Mokslinių tyrimų kryptys: neformaliojo ir savaiminio mokymosi vertinimas bei pripažinimas, profesinès anglų kalbos studijos aukštajame moksle, inovaciniai studijų metodai, technologijų taikymas švietime.

Jolita Šliogerienė, Mykolas Romeris University, Faculty of Politics and Management, Institute of Philosophy and Humanities, Professor. Research interests: assessment and recognition of non-formal and informal learning, ESP studies in higher education, innovative study methods, application of technology in education.

Giedrẻ Valūnaite Oleškevičienė, Mykolo Romerio universiteto Politikos ir vadybos fakulteto Filosofijos ir humanistikos instituto lektorè. Mokslinių tyrimų kryptys: suaugusiųjų mokymasis, kūrybiškumo skatinimas, profesinès anglų kalbos studijos aukštajame moksle, inovaciniai studijų metodai, technologijų taikymas švietime.

Giedrè Valūnaite Oleškevičienè, Mykolas Romeris University, Faculty of Politics and Management, Institute of Philosophy and Humanities, lektoré. Research interests: adult learning, creativity development, ESP studies in higher education, innovative teaching and study methods, technology application in education. 